slowed to one case in May and one in June. Matsuzawa is holding back some data for a more detailed future publication and would not answer Nature's questions about whether his group is also probing possible environmental causes, which bacteria and viruses have been tested for, and what analysis of the two surviving monkeys has revealed.

By screening the 790 remaining Japanese macaques for other viruses and bacteria and running genetic tests, Matsuzawa hopes to pin down the cause of the syndrome and to create a test for early diagnosis. He says that he is looking for collaborators, and animalpathogen researchers contacted by Nature are certainly eager to learn more about the illness. Primate disease specialist Sonia Altizer of the University of Georgia in Athens wonders whether any of the animals were recently captured in the wild, where they could have picked up the infection, and whether animals were housed singly or in groups. "Knowing the possible contacts between animals and the chronological pattern of illness or deaths might also help determine whether this was indeed an infectious agent, and the possible routes of transmission," she says.

She also asks what measures the human workers were taking before the outbreaks to minimize transmission of infectious agents between monkeys and humans. "Presumably there would be some pretty careful measures in place that would limit human exposure to any contaminant or pathogen," she says, "so saying that humans are not susceptible to me seems premature" David Cyranoski

hit by a mine or rammed by another ship a suggestion also raised by Shin Sang-chul, a former officer in the South Korean navy who was part of the investigation team.

This week, a US-led UN team plans to meet North Korean military representatives to discuss the sinking. The South Korean government has adamantly denied fabrication or major problems with its interpretation of the data. Others also doubt that there is an alternative interpretation. "Aside from the science, it is consistent with North Korea's behaviour in the past," says James Schoff, an Asian regional security expert at the Institute for Foreign Policy Analysis in Cambridge, Massachusetts. Referring to South Korea's investigation, he says: "I have no doubts personally that the conclusion is correct." David Cyranoski

See go.nature.com/5q5igr for a longer version of this story.

\title{
Start-up model patently flawed
}

It is widely believed to be the standard route for academics starting their own business: disclose an invention to the university, get it patented and venture forth into the spin-out world. But an extensive survey has found that this is not how the majority of companies are started by US academics, suggesting that government and universities are missing an opportunity in their quest to boost entrepreneurial activity.

In what the authors say is the largest study of its kind, experts on entrepreneurship surveyed 11,572 professors at institutions across the United States (R. Fini, N. Lacetera and S. Shane Res. Pol. doi:10.1016/ j.respol.2010.05.014; 2010). Of the 1,948 respondents who had started a business, only 682 , or about one-third, had set them up to exploit patents obtained through formal university intellectual-property systems. The remaining 1,266 respondents had started businesses - including consultancies and manufacturing and service-based firms - based on nonpatentable knowledge.

Social scientists and engineers started the most businesses that were not based on patented inventions, but such ventures were also prevalent among biomedical and physical scientists (see 'Unexpected entrepreneurs').

"There is a lot of stuff that academics are realizing isn't patentable but they can commercialize for themselves by starting a company," says Scott Shane, an economist at Case Western Reserve University in Cleveland, Ohio, and a co-author of the study. Because surveys of entrepreneurial activity - including government assessments - typically focus on patent activity, they may be significantly underestimating academics' efforts, he notes.

The study also says that universities' technology-transfer offices (TTOs) are "failing to help" a sizeable proportion of academic entrepreneurs. "If you aren't measuring [the full range of activities] you can't promote them," says Shane. "All the policies and approaches focus on the formal intellectual-property system, which means we are missing a big part of the iceberg that is under the water."

Ashley Stevens, president of the Association of University Technology Managers, calls the study "a significant new piece of data". But he says that TTOs do help academic entrepreneurs outside
UNEXPECTED ENTREPRENEURS

Many academics' businesses are not underpinned by patents.

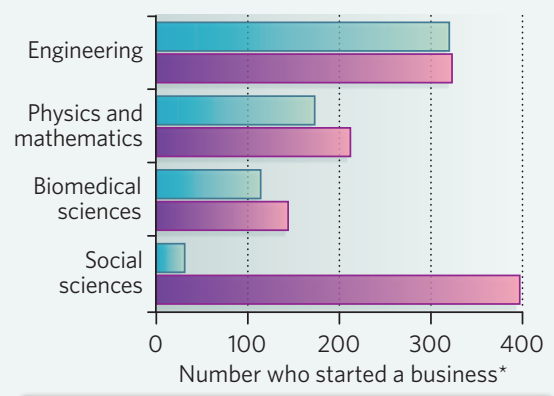

Based on patent $\square$ Not based on patent *Based on 1,714 respondents who provided information about their discipline

the formal intellectual-property system. A major barrier to more support is that, unlike businesses started inside the system, those started without patents are less likely to provide the university with a financial return, he adds.

Yet the survey found no discernible difference in respondents' financial return between businesses started with and without patents, although those businesses not based on patents were more likely to fail.

The study comes as the US government is shaping its policy on the commercialization of federally funded research. The Office of Science and Technology Policy put out a call for information earlier this year, and is promising to use the results to help identify a set of "promising practices" that will encourage technology commercialization, says Tom Kalil, the office's deputy director for policy. "These include entrepreneurship education for faculty and students, proof-ofconcept funding, standardized intellectualproperty agreements, and policies that allow faculty to take 'industrial leave' to start up a company."

Some experts say that governments and universities are still right to focus on patent-based academic entrepreneurship. Businesses built on inventions tend to need more support to establish themselves, and can potentially generate the greatest returns, says Mark Schankerman, who studies entrepreneurship at the London School of Economics. "It is getting out a new drug, not a new consultancy company, which is going to make the larger contribution to the economy and society," he says.

Zoë Corbyn 